\title{
MORPHOLOGICAL CHANGES IN THE DIGESTIVE SYSTEM OF 93 HUMAN IMMUNODEFICIENCY VIRUS POSITIVE PATIENTS: AN AUTOPSY STUDY
}

Lucinda Calheiros GUIMARÃES(1), Ana Cristina Araujo Lemos SILVA(1), Adilha Misson Rua MICHELETTI(1), Everton Nunes Melo MOURA(2), Mario Leon SILVA-VERGARA(3) \& Sheila Jorge ADAD(1)

\begin{abstract}
SUMMARY
Involvement of the digestive system in patients with acquired immunodeficiency syndrome (AIDS) is frequent and many changes in these patients are diagnosed only at autopsy. There are few studies of autopsy with detailed analysis of this system and only one was conducted in Brazil. We evaluated each segment of the digestive system in 93 consecutive autopsies of patients infected with human immunodeficiency virus (HIV) and the importance of these lesions to death. Of these, 90 (96.8\%) patients had AIDS. We reviewed medical records, autopsy reports and histological sections from tongue to rectum stained with hematoxylin-eosin. When necessary, we analyzed special stains and immunohistochemistry to investigate infections. There was damage to the digestive system in 73 (78.5\%) cases. The most common infections were candidiasis (42\%), cytomegalovirus (29\%), histoplasmosis (11.8\%), toxoplasmosis (9.7\%) and mycobacterial infection (9.7\%). Malignancies were rare, present in four (4.3\%) cases (two Kaposi's sarcoma, one adenocarcinoma and one metastatic embryonal carcinoma). All segments showed lesions: tongue (48.6\%), esophagus (44.8\%), stomach (44.7\%), colon $(43.2 \%)$ and small intestine (28.9\%). The lesions found were immediate cause of death in five (5.4\%) cases. In another 36 (38.7\%) cases the basic disease was systemic and also compromised the digestive system.
\end{abstract}

KEYWORDS: Autopsy; Pathology; HIV; Acquired Immunodeficiency Syndrome; Digestive system; Gastrointestinal tract.

\section{INTRODUCTION}

Digestive system involvement in patients with acquired immunodeficiency syndrome (AIDS) occurs very often and includes a wide range of infections and neoplasms. Epidemiologic differences, both regional and between different countries are showed in Latin American and African studies when compared to North American and European studies ${ }^{11,24,25,26}$. Several changes in the digestive system are observed only at autopsy $y^{3,19,20}$, however, there is only one study specifically evaluating the scope of gastrointestinal pathology in AIDS in Brazil ${ }^{5}$ and another one elsewhere ${ }^{22}$. The aim of this study was to identify morphological changes in each segment of the digestive system associated to human immunodeficiency virus (HIV) infection and to AIDS and also to know the importance of these lesions related to death. Despite reduction in the number of autopsies being a global trend, such procedures are still important for teaching medical students, pathologists and clinicians who have treated the patient, and these are methods for quality control of medical care. A better knowledge of gastrointestinal disorders associated to HIV infection and to AIDS may help in prophylaxis and treatment of patients in our region and elsewhere.

\section{MATERIAL AND METHODS}

This is a retrospective study of the digestive system in consecutive autopsies of HIV positive individuals from 1989, the year that the first autopsy of individuals with AIDS was held in a 290 beds public teaching hospital that provides care of high complexity, located in Uberaba, Minas Gerais, until December 1996. All patients with HIV positive serology were initially included and diagnosis of AIDS was based on CDC criteria ${ }^{6,7}$. This period is prior to introduction of HAART (Highly Active Antiretroviral Therapy) to treatment of AIDS patients. In this period 96 autopsies of HIV positive individuals were carried out, however, three cases were excluded from this study due to lack of histological sections and reserve fragments of the digestive system organs fixed in formaldehyde. Then, the final number of cases is 93. All histological slides were reviewed by one pathologist (first author) and doubtful cases were reviewed by two pathologists (first and last authors). When necessary, new histological slides were performed. When infection was morphologically suspected, special stains were realized for detection of mycobacteria (Fite-Faraco) and fungi (Grocott, Periodic-Acid Schiff and mucicarmin) and immunohistochemistry for Toxoplasma gondii, cytomegalovirus (CMV), herpes simplex virus, human papillomavirus and Epstein-Barr virus.

In a schedule, we described gross and microscopic alterations found in autopsy reports and also in histological sections of tongue, esophagus, stomach, small bowel and large bowel, as well as relevant clinical information relating to death. There were no histological sections of all these segments available in all cases. Then, the results will be presented

(1) Discipline of Special Pathology, Universidade Federal do Triângulo Mineiro (UFTM), Uberaba, Minas Gerais, Brazil.

(2) Medical Student, Universidade Federal do Triângulo Mineiro (UFTM), Uberaba, Minas Gerais, Brazil.

(3) Discipline of Infectious and Parasitary Diseases, Universidade Federal do Triângulo Mineiro (UFTM), Uberaba, Minas Gerais, Brazil.

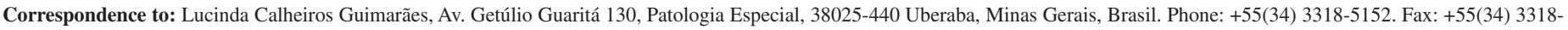
5846. E-mail: lucindaguimaraes@yahoo.com.br 
GUIMARÃES, L.C.; SILVA, A.C.A.L.; MICHELETTI, A.M.R.; MOURA, E.N.M.; SILVA-VERGARA, M.L. \& ADAD, S.J. - Morphological changes in the digestive system of 93 human immunodeficiency virus positive patients: an autopsy study. Rev. Inst. Med. Trop. Sao Paulo, 54(2): 89-93, 2012.

as percentage of total number of cases evaluated in each segment of the digestive system. Through study of medical records we analyzed the importance of gastrointestinal disorders in relation to clinical findings and patient death.

The research project of this study was approved by Ethics in Research of our institution at Feb29, 2008 (protocol number 1063).

\section{RESULTS}

Among 93 cases studied, 77 (82.8\%) were male and $16(17.2 \%)$ females, only three patients did not have clinical criteria for $\operatorname{AIDS}^{7}$. Ages ranged from two months to 67 years, mean $33.2 \pm 11.3$ and median of 30 years. There was only one child. This male child, in spite of lacking serological confirmatory tests (enzyme-linked immunosorbent assay was positive, but Western blot wasn't available), presented chronic diarrhea for more than 30 days, wasting syndrome and concomitant diseases at death (bacterial pneumonia and pulmonary aspergillosis, the last one diagnosed at necropsy). Indeed, his mother had AIDS, which allows the same diagnosis in the child, perinatally exposed ${ }^{6}$.

Regarding pathologic evaluation, digestive lesions were found in $78.5 \%$ of cases. The spectrum of infectious agents and neoplasms identified is shown in Table 1 . The most common disorders were infections, present in $76.3 \%$ of cases. Neoplasms have been identified only in $4.3 \%$ of cases. In several cases there were different diseases simultaneously present.

Analysis of all segments of the digestive system showed that the most frequent infection was candidiasis, found in $42 \%$ of cases, followed by cytomegalovirus (29\%), histoplasmosis $(11.8 \%)$, toxoplasmosis $(9.7 \%)$ and mycobacteria infection $(9.7 \%)$. Concerning neoplasias there were disseminated Kaposi`s sarcoma (2.1\%), gastric adenocarcinoma (1.1\%) and metastatic embryonal carcinoma to intestinal serosa (1.1\%). The last two neoplasias are not related to AIDS, but the patient affected by gastric adenocarcinoma had AIDS and opportunistic infections.

Concerning the segments of the digestive system, changes were observed in all segments studied: tongue (48.6\%), esophagus (44.8\%), stomach $(44.7 \%)$, large bowel (43.2\%) and small bowel (28.9\%).

Microscopic analysis of tongue was possible in 76 cases, while changes were observed in $48.6 \%$ of them. Candidiasis was the most frequent diagnosis, present in $36.8 \%$ of cases. Multiple lesions were reported in association with candidiasis: oral hairy leukoplakia, histoplasmosis, paracoccidioidomycosis, cryptococcosis, and concomitant infection by Candida sp, Toxoplasma gondii and CMV. Oral hairy leukoplakia was isolated observed in $5.3 \%$ of cases. Histoplasmosis, cryptococcosis, and mycobacterial infection were isolated found in $3.9 \%$, $1.3 \%$ and $1.3 \%$, respectively.

The most common abnormality in esophagus was also candidiasis, present in $20.5 \%$ of 78 cases microscopically examined. There was association with other infectious agents (herpes simplex virus, Histoplasma capsulatum and CMV). It was noted CMV infection in $18 \%$ and toxoplasmosis in $5.1 \%$ of cases. In both infections, other agents were present simultaneously. Other infectious agents isolated found in esophagus included Histoplasma capsulatum (1.3\%), Toxoplasma gondii
Table 1

Main morphological lesions in the digestive system found in 93 autopsies of HIV positive patients

\begin{tabular}{lll}
\hline Lesion & $\mathrm{n}$ & $\%$ \\
\hline
\end{tabular}

INFECTION

\section{Protozoan}

$\begin{array}{lcc}\text { T. gondii } & 9 & 9.7 \\ \text { Cryptosporidium } & 2 & 2.1 \\ \text { Isospora } & 1 & 1.1 \\ \text { ngi } & & \\ \text { Candida sp } & 39 & 42.0 \\ \text { H. capsulatum } & 11 & 11.8 \\ \text { C. neoformans } & 3 & 3.2 \\ \text { P. brasiliensis } & 2 & 2.1\end{array}$

\section{Bacteria}

Mycobacteria

9

9.7

Virus

$\begin{array}{lcc}\text { Citomegalovirus } & 27 & 29.0 \\ \text { Herpes simplex } & 3 & 3.2\end{array}$

Worms

$\begin{array}{lll}\text { S. stercoralis } & 4 & 4.3 \\ \text { A. lumbricoides } & 3 & 3.2 \\ \text { Taenia } & 1 & 1.1\end{array}$

\section{NEOPLASIAS}

$\begin{array}{lll}\text { Kaposi sarcoma } & 2 & 2.1 \\ \text { Gastric adenocarcinoma } & 1 & 1.1 \\ \text { Metastatic embryonal carcinoma } & 1 & 1.1\end{array}$

Note: Multiple infectious agents were simultaneously present in some cases; $\mathrm{n}=$ number of cases.

(2.6\%, included in the previous cited cases) and mycobacteria (2.6\%). There was only one case (1.3\%) of neoplasia (Kaposi's sarcoma), which compromised, beyond the esophagus, stomach and intestines.

In stomach, we observed changes of infectious, peptic/inflammatory and neoplastic nature in $44.7 \%$ of 85 cases microscopically examined. CMV infection was present in $12.9 \%$ of cases, some of them in association with other infectious agents (Cryptosporidium, Candida sp and Toxoplasma gondii). Infectious diseases isolated found in stomach were strongyloidiasis (3.5\%), cryptococcosis (3.5\%), toxoplasmosis (2.4\%), histoplasmosis (1.2\%) and cryptosporidiosis (1.2\%). Peptic and inflammatory changes included infection by $H$. pylori $(1.2 \%)$, chronic gastritis (5.9\%), chronic peptic ulcers (3.5\%) and erosions/acute ulcerations (5.9\%). The latter were source of bleeding and contributed to the death of these patients. Three cases presented gastric neoplasias: two $(2.4 \%)$ Kaposi sarcoma widespread and one (1.2\%) signet ring cell adenocarcinoma. At the last one, an upper gastrointestinal bleeding from ulcerated tumor was the cause of death. 


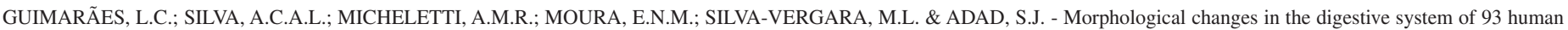
immunodeficiency virus positive patients: an autopsy study. Rev. Inst. Med. Trop. Sao Paulo, 54(2): 89-93, 2012.

The small bowel was the least affected segment in percentage terms. Changes were observed in $28.9 \%$ of 88 cases in which histological analysis was possible. The most common abnormality was CMV infection, present in $6.8 \%$ of cases. Other isolated infections were mycobacterial infection $(4.5 \%)$, histoplasmosis $(4.5 \%)$, ascaridiasis (3.4\%), strongyloidiasis $(2.2 \%)$, cryptococcosis $(2.2 \%)$, toxoplasmosis $(1.1 \%)$ and cryptosporidiosis $(1.1 \%)$. Kaposi sarcoma was observed in $2.2 \%$ previous cited cases in which there was simultaneous involvement of stomach. In one case, peptic lesions were seen (two chronic duodenal ulcers) without relevant bleeding.

In large bowel, $43.2 \%$ of 88 cases microscopically examined showed morphological changes. The most common infection was by CMV, found in $13.6 \%$ of cases. Four of them showed an association with another infectious agent (Cryptosporidium, Candida sp, Paracoccidioides brasiliensis and Histoplasma capsulatum). Isolated infections by Histoplasma capsulatum (8\%), Paracoccidioides brasiliensis $(1.1 \%)$ and Candida sp (1.1\%) were also observed. Among protozoan infections, one case of Isospora infection (1.1\%) was noted. Other infections seen in large bowel were mycobacterial infection (8\%), strongyloidiasis $(3.4 \%)$, toxoplasmosis $(2.2 \%)$, taeniasis $(1.1 \%)$ and cryptococcosis $(1.1 \%)$. Regarding to neoplasias, metastatic embryonal carcinoma in intestinal serosa $(1.1 \%)$ and Kaposi`s sarcoma $(1.1 \%)$ were observed.

Among the 93 autopsies studied, in 41 (44\%) disease causing death also compromised the digestive system and in five of these, immediate death cause was located in this system. In these five patients, death was caused by hypovolemic shock due to gastrointestinal bleeding secondary to: Mallory-Weiss syndrome in an alcoholic patient, HIVinfected, but without AIDS; extensive, necro-hemorrhagic esophagitis due to Candida sp, Histoplasma capsulatum and herpes simplex virus infection simultaneously, added to Histoplasma capsulatum hemorrhagic enterocolitis; ulcerated gastric signet-ring cell adenocarcinoma; ulcerated intestinal tuberculosis; acute gastric ulcers with large bowel infarct in a HIV-infected patient, but without AIDS. In the remaining 36 cases, the main cause of death was systemic infectious diseases or widespread neoplasms that involved the digestive system (Table 2).

\section{Table 2}

Aids associated diseases (causes of death) with gastrointestinal involvement in 93 autopsies of HIV positive patients

\begin{tabular}{lcc}
\hline Disease & $\mathrm{n}$ & $\%$ \\
\hline Histoplasmosis & 11 & 11.8 \\
Mycobacterial infection & 9 & 9.7 \\
Toxoplasmosis & 7 & 7.5 \\
Cryptococcosis & 3 & 3.2 \\
Cytomegalovirosis & 2 & 2.2 \\
Paracoccidioidomycosis & 2 & 2.2 \\
Candidiasis & 1 & 1.1 \\
Kaposi Sarcoma & 1 & 1.1 \\
\hline TOTAL & $\mathbf{3 6}$ & $\mathbf{3 8 . 7}$ \\
\hline
\end{tabular}

$\mathrm{n}=$ number of cases

\section{DISCUSSION}

In literature, there are only two studies ${ }^{5,22}$ that show changes in the digestive system in detail and by segment as we did. In our study the digestive system involvement occurred in $78.5 \%$ of cases, a rate similar to an autopsy work that evaluated only the digestive system, conducted in a teaching public hospital in Botucatu, Brazil, in which it occurred in $82.3 \%$ of 45 cases $^{5}$.

In our assessment, tongue was the most affected organ (48.6\%). This rate is lower than other studies ${ }^{5,13}$, in which mouth was much more commonly affected. This difference is probably due to methodology used, because, instead of the cited work ${ }^{5}$, we did not do a global study of oral cavity, but only of tongue. In our study we found $8 \%$ of cases of oral hairy leukoplakia, while other works found this lesion as the most frequent, present in $35.5 \%$ of 45 autopsies and in $45.6 \%$ of 92 autopsies, respectively ${ }^{5,13}$. It is possible that some of this difference is related to sampling for microscopy. In our study, tongue was sampled randomly or in sites with macroscopic lesion, instead of another autopsy study that exclusively evaluated tongue, in which several regions were represented histologically by prior standardization ${ }^{13}$. Moreover, another factor that may explain this difference is the subjectivity in microscopic evaluation of lesion, based mainly in morphological criteria ${ }^{14}$. Furthermore, treatment with antiviral drugs may have contributed to a low number of cases of this condition ${ }^{23}$. LEONARD et al. have found only $5 \%$ of oral hairy leukoplakia in a study of 20 autopsies ${ }^{23}$.

Evaluating other segments, we also noticed a predominance of infectious lesions over the neoplastic ones.

Considering the entire digestive system, Candida sp was the most frequent infection. In our study, we found infection by Candida sp affecting mainly tongue and esophagus, but also stomach and large bowel. In two of these cases, candidiasis was associated with CMV infection. Mucosal ulcers caused by CMV may have superinfection by fungi and bacteria, justifying this association. Candidiasis is usually seen in mucosal surfaces, occasionally invading deep tissues and producing systemic disease $^{16}$. In our study, one patient with oral candidiasis developed pulmonary involvement that caused death.

CMV infection was the second most common infection. Other studies showed the digestive system as one of the most usual sites of this infection ${ }^{9,17,21}$. In India, a study of the digestive system in 49 autopsies showed CMV in $27 \%$ of cases $^{22}$. We found CMV infection in all segments investigated, being the most common infection in large bowel, stomach and small bowel. Clinical consequences of CMV infection are varied, one can observe little or no tissue reaction in the organ involved. Patients do not usually have gastrointestinal symptoms. Advanced disease is represented by mucosa erosion or ulceration, causing watery diarrhea indistinguishable from other causes of diarrhea in HIV positive patients ${ }^{28}$, making it necessary to perform biopsies of lesions for a definitive diagnosis. However, because of poor health status of many patients it is impossible to undertake upper endoscopy or colonoscopy for tissue sampling. CMV infection should therefore always be in differential diagnosis of HIV positive patients with digestive symptoms.

The third most common infection was histoplasmosis, a mycosis, whose via of infection is respiratory, with development of granulomatous 


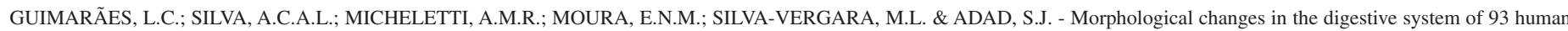
immunodeficiency virus positive patients: an autopsy study. Rev. Inst. Med. Trop. Sao Paulo, 54(2): 89-93, 2012

reaction in lung parenchyma and regional lymph nodes, similar to that seen in first infection by $M$. tuberculosis, usually progressing to scarring and calcification of involved regions. Concerning to histoplasmosis, it is important to identify endemic areas of this disease, since fungus is usually dead on the former primary complex and systemic disease is usually secondary to exogenous infection ${ }^{1}$. In our study, we found Histoplasma capsulatum in all segments of the digestive system investigated and all involved patients had disseminated disease. Other studies specifically evaluating the digestive system found only $6.6 \%$ and no one case of histoplasmosis in this site, respectively ${ }^{5,22}$. A study, conducted at Universidade Federal de Uberlândia, the same geographical region where our study was developed, has found histoplasmosis in $11.5 \%$ of 52 autopsies of AIDS, one of them having intestinal involvement ${ }^{3}$. These differences are probably due to geographical and regional variations in incidence of histoplasmosis. The frequency seen in the study in Uberlândia $^{3}$ (11.5\%) was similar to our study (11.8\%), which may suggest that Triângulo Mineiro is really an endemic area of histoplasmosis, since data from literature ${ }^{1}$ seems to indicate that AIDS patients who develop histoplasmosis live in endemic areas.

Toxoplasmosis occurred in $9.7 \%$ of cases. In our study, Toxoplasma gondii forms were found in all segments of the digestive system evaluated. Autopsy studies evaluating the digestive system of patients with AIDS do not report the finding of toxoplasmosis at this site ${ }^{5,22}$. The Brazilian study of Uberlândia reports $4 \%$ cases of toxoplasmosis in 52 autopsies ${ }^{3}$. Two of them had involvement of esophagus, stomach and intestine. The high frequency of toxoplasmosis in a French study ${ }^{18}$ (26\% in 395 autopsies) was attributed to the high prevalence of Toxoplasma gondii infection in France. In Brazil, the prevalence of Toxoplasma gondii antibodies in general population ranges from $50 \%$ to $80 \%{ }^{15}$, which could explain the finding of disseminated disease also affecting the digestive system in patients with AIDS. The differences in rates of the digestive system infection by Toxoplasma gondii may also be attributed to difficult identification of this agent in histological sections, which often requires immunohistochemical techniques.

With regard to infection by mycobacteria, acid-fast bacilli were found involving tongue, esophagus and bowel. In literature there is a wide variation in the rate of mycobacterial infection in the digestive system. In a study of 350 autopsies, the authors demonstrated mycobacterial infection affecting the digestive system in $2 \%$ of cases $^{10}$. In India, involvement was found in $14 \%$ of 49 autopsied patients ${ }^{22}$. In these two studies there was a higher rate of infection with $M$. tuberculosis compared to atypical mycobacteria, in contrast to North American findings, dominated by atypical mycobacterial infection ${ }^{27}$. Our result is closer to a Brazilian study, in which mycobacterial infection in the digestive system was found in $6.7 \%$ of 45 autopsies ${ }^{5}$. In these two Brazilian studies mycobacterial culture was not performed, and therefore it was not possible to define the specie of bacilli.

We have observed other less frequent infections, viral (herpes simplex), fungal (cryptococcosis and paracoccidioidomycosis), parasitic helminth infestation (ascaridiasis, taeniasis and strongyloidiasis) and by protozoa (isosporiasis and cryptosporidiosis). Note rare meeting of these two protozoa at autopsy, although they are common pathogens in HIV positive patients. This fact is probably due to autolysis that occurs in the digestive system in autopsy material, making it difficult to notice parasites infecting mucosal surface, as also happens with $H$. pylori infection, a difficulty reported by other authors in autopsy studies ${ }^{5,11}$.

Many patients had lesions with more than one etiology, a common condition in AIDS patients 5 .

Leishmania was not noted in this study. The two infectious agents that could be misdiagnosed as Leishmania were Toxoplasma gondii and Histoplasma capsulatum. Both these agents were confirmed by special techniques: immunohistochemistry for Toxoplasma gondii and Grocott stain for Histoplasma capsulatum. Moreover, Uberaba is not an endemic area for leishmaniasis, which occurs as an endemic disease in other regions of Minas Gerais ${ }^{2,12}$. In a search realized in biopsy and necropsy archives of this service since 1994 (data not published), there were only 24 biopsy cases with morphologic confirmation of American cutaneous leishmaniasis and two autopsy cases of visceral leishmaniasis. In all these cases, the patients were not autochthonous or recently visited an endemic area.

With respect to neoplasias, our results are consistent with previous Brazilian $^{8,17,25}$ studies, which reported low incidence of malignancies in HIV positive patients when compared to North American and European results. In our study, only $4.3 \%$ patients had tumors affecting the digestive system. In another autopsy study of the digestive system tumors were observed in $15.5 \%$ of 45 autopsies reviewed ${ }^{5}$. In a multisystemic Brazilian study there were only $3.2 \%$ of neoplasias in 92 autopsied patients with AIDS . $^{8}$

According to Table 2, in $38.7 \%$ of cases, systemic infections and neoplasias causing death committed, also, the digestive system, confirming the importance of this system as host of pathological changes related to HIV infection and AIDS. Among the five patients who died secondary to gastrointestinal bleeding, two did not have AIDS, finding also noted in a clinical study ${ }^{4}$ which reported high mortality rate in patients HIV positive without AIDS due to, for example, the high frequency of alcoholism and other diseases.

This is the first step in a research project that includes a comparison between pre and post-HAART evaluation of the digestive system in HIV-infected autopsies.

\section{RESUMO}

\section{Alterações morfológicas no sistema digestivo de 93 pacientes infectados pelo vírus da imunodeficiência humana: um estudo de autopsias}

Envolvimento do sistema digestório em pacientes com síndrome da imunodeficiência adquirida (AIDS) é frequente e muitas alterações nesses pacientes são diagnosticadas apenas à autopsia. Há escassos estudos de autopsia com análise detalhada desse sistema e apenas um deles foi realizado no Brasil. Neste estudo avaliamos cada segmento do sistema digestório em 93 autopsias consecutivas de indivíduos infectados pelo vírus da imunodeficiência humana (HIV) e a importância dessas lesões para o óbito. Desses, 90 (96,8\%) pacientes apresentavam AIDS. Revisamos prontuários médicos, relatórios de autopsias e cortes histológicos da língua ao reto corados pela técnica de hematoxilinaeosina. Quando necessário, analisamos colorações especiais e imunohistoquímica para pesquisar infecções. Havia lesões no sistema digestório 
GUIMARÃES, L.C.; SILVA, A.C.A.L.; MICHELETTI, A.M.R.; MOURA, E.N.M.; SILVA-VERGARA, M.L. \& ADAD, S.J. - Morphological changes in the digestive system of 93 human immunodeficiency virus positive patients: an autopsy study. Rev. Inst. Med. Trop. Sao Paulo, 54(2): 89-93, 2012.

em $73(78,5 \%)$ casos. As alterações mais comuns foram infecciosas: candidíase $(42 \%)$, citomegalovirose $(29 \%)$, histoplasmose $(11,8 \%)$, toxoplasmose $(9,7 \%)$ e infecção por micobactérias $(9,7 \%)$. Neoplasias malignas foram raras, presentes em quatro $(4,3 \%)$ casos (dois sarcomas de Kaposi, um adenocarcinoma gástrico e um carcinoma embrionário metastático). Todos os segmentos apresentaram lesões: língua $(48,6 \%)$, esôfago $(44,8 \%)$, estômago $(44,7 \%)$, intestino grosso $(43,2 \%)$ e intestino delgado $(28,9 \%)$. As lesões encontradas foram causa imediata do óbito em cinco $(5,4 \%)$ casos. Em outros $36(38,7 \%)$ casos a doença básica era sistêmica comprometendo, também, o sistema digestório.

\section{ACKNOWLEDGMENTS}

This study was financially funded by FUNEPU (Fundação de Ensino e Pesquisa de Uberaba: Grant $n^{\circ}$ 584/2008) and FAPEMIG (Fundação de Amparo à Pesquisa do Estado de Minas Gerais: Grant $n^{\circ} \mathrm{APQ} 5583$ 4.01-07/Scientific initiation program).

\section{REFERENCES}

1. Adad SJ, Machado ME, Batista FC. Histoplasmose residual dos pulmões e linfonodos broncopulmonares em necropsias realizadas em Uberaba, MG. Rev Soc Bras Med Trop. 1996;29:491-6.

2. Badaró R, Duarte MIS. Leishmaniose visceral (Calazar). In: Focaccia R, editor. Veronesi: tratado de Infectologia. $3^{\text {rd }}$ ed. São Paulo: Atheneu; 2005. p. 1559-88.

3. Borges AS, Ferreira MS, Nishioka SA, Silvestre MTA, Silva AM, Rocha A. Agreement between premortem and postmortem diagnoses in patients with acquired immunodeficiency syndrome observed at a Brazilian teaching hospital. Rev Inst Med Trop São Paulo. 1997;39:217-21.

4. Cappell MS, Geller AJ. The high mortality of gastrointestinal bleeding in HIVseropositive patients: a multivariate analysis of risk factors and warning signs of mortality in 50 consecutive patients. Am J Gastroenterol. 1992;87:815-24.

5. Carvalho MG, Rodrigues MA, Marques ME, Franco M, Montenegro MR. Lesões do trato gastrointestinal na síndrome da imunodeficiência adquirida: estudo de 45 necropsias consecutivas. Rev Soc Bras Med Trop. 1994;27:135-41.

6. CDC - Centers for Disease Control and Prevention. 1994 Revised classification system for human immunodeficiency virus infection in children less than 13 years of age. MMWR. 1994;43(RR-12):1-10. Available from: http://www.cdc.gov/mmwr/ preview/mmwrhtml/00032890.htm. (cited: 2011, November 22).

7. CDC - Centers for Disease Control and Prevention. 1993 Revised classification system for HIV infection and expanded surveillance case definition forAIDS among adolescents and adults. MMWR. 1992;41(RR-17). Available from: www.cdc.gov/ mmwr/preview/mmwrhtml/00018871.htm (cited: 2011, November 10).

8. Cury PM, Pulido CF, Furtado VM, Palma FM. Autopsy findings in AIDS patients from a reference hospital in Brazil: analysis of 92 cases. Pathol Res Pract. 2003;199:811-4.

9. d'Arminio Monforte A, Mainini F, Testa L, Vago L, Balotta L, Nebuloni M, et al. Predictors of cytomegalovirus disease, natural history and autopsy findings in a cohort of patients with AIDS. AIDS. 1997;11:517-24.

10. d'Arminio Monforte A, Vago L, Gori A, Antinori S, Franzetti, F, Antonacci CM, et al. Clinical diagnosis of mycobacterial diseases versus autopsy findings in 350 patients with AIDS. Eur J Clin Microbiol Infect Dis. 1996;15:453-8.

11. Eza D, Cerrillo G, Moore DA, Castro C, Ticona E, Morales D, et al. Postmortem findings and opportunistic infections in HIV-positive patients from a public hospital in Peru. Pathol Res Pract. 2006;202:767-75.
12. Falqueto A, Sessa PA. Leishmaniose tegumentar americana. In: Focaccia R, editor. Veronesi: tratado de Infectologia. $3^{\text {rd }}$ ed. São Paulo: Atheneu; 2005. p. 1543-57.

13. Faria PR, Vargas PA, Saldiva PHN, Böhm GM, Mauad T, Almeida OP. Tongue disease in advanced AIDS. Oral Dis. 2005;11:72-80.

14. Fernández JF, Benito MA, Lizaldez EB, Montañés MA. Oral hairy leukoplakia: a histopathologic study of 32 cases. Am J Dermatopathol. 1990;12:571-8.

15. Frenkel JK, Bermudéz JEV. Toxoplasmose. In: Focaccia R, editor. Veronesi: tratado de Infectologia. $3^{\text {rd }}$ ed. São Paulo: Atheneu; 2005. p. 1633-50.

16. Görnig M, Emmert-Buck M, Walsh TJ. Merkmale der Candida-ösophagitis bei tumor-und AIDS-patienten: histopathologische studie an 23 patienten. Mycoses. 1997;40(Suppl 1):81-5. Available from: http://onlinelibrary.wiley.com/ doi/10.1111/j.1439-0507.1997.tb00547.x/abstract (cited: 2011, January 28).

17. Guidugli Netto J, Collarile DC, Borges AFA, Biancalana MLN, Stefano HNV. Achados necroscópicos em pacientes com síndrome da imunodeficiência adquirida. Rev Paul Med. 1990;108:205-12.

18. Hofman P, Saint-Paul MC, Battaglione V, Michiels JF, Loubière R. Autopsy findings in the acquired immunodeficiency syndrome (AIDS). A report of 395 cases from the south of France. Pathol Res Pract. 1999;195:209-17.

19. Hui AN, Koss MN, Meyer PR. Necropsy findings in acquired immunodeficiency syndrome: a comparison of premortem diagnoses with postmortem findings. Hum Pathol. 1984;15:670-6.

20. Klatt EC, Nichols L, Noguchi TT. Evolving trends revealed by autopsies of patients with the acquired immunodeficiency syndrome: 565 autopsies in adults with the acquired immunodeficiency syndrome, Los Angeles, Calif, 1992-1993. Arch Pathol Lab Med. 1994;118:884-90.

21. Klatt EC, Shibata D. Cytomegalovirus infection in the acquired immunodeficiency syndrome. Clinical and autopsy findings. Arch Pathol Lab Med. 1988;112:540-4.

22. Lanjewar DN, Anand BS, Genta R, Maheshwari MB, Ansari MA, Hira SK, et al. Major differences in the spectrum of gastrointestinal infections associated with AIDS in India versus the west: an autopsy study. Clin Infect Dis. 1996;23:482-5.

23. Leonard N, McCreary C, Flint SF, Mabruk MJEMF, Mulcahy F, Toner M. Autopsy findings in the tongues of 20 patients with AIDS. J Oral Pathol Med. 1997;26:244-7.

24. Lucas SB, Hounnou A, Peacock C, Beaumel A, Djomand G, N'gbichi J, et al. The mortality and pathology of HIV infection in a west African city. AIDS. 1993;7:156979.

25. Michalany J, Mattos AL, Michalany NS, Filie AC, Montezzo LC. Acquired immune deficiency syndrome (AIDS) in Brazil. Necropsy findings. Ann Pathol.1987;7:15-24.

26. Mohar A, Romo J, Salido F, Jessurun J, Ponce de León S, Reyes E, et al. The spectrum of clinical and pathological manifestations of AIDS in a consecutive series of autopsied patients in Mexico. AIDS. 1992;6:467-73.

27. Wilkes MS, Fortin AH, Felix JC, Godwin TA, Thompson WG. Value of necropsy in acquired immunodeficiency syndrome. Lancet. 1988;2(8602):85-8.

28. Yarrish RL. Cytomegalovirus infections in AIDS. In: Wormser GP, editor. AIDS and other manifestations of HIV- infections. $2^{\text {nd }}$ ed. New York: Raven Press; 1992. p. 249-68.

Received: 22 August 2011

Accepted: 1 February 2012 


\section{Revista do Instituto de Medicina Tropical de São Paulo on line.}

Publications from 1987 to the present data are now available on:

http://www.scielo.br/rimtsp

PAST ISSUES 1959-1989 (PDF)

www.imt.usp.br/portal/

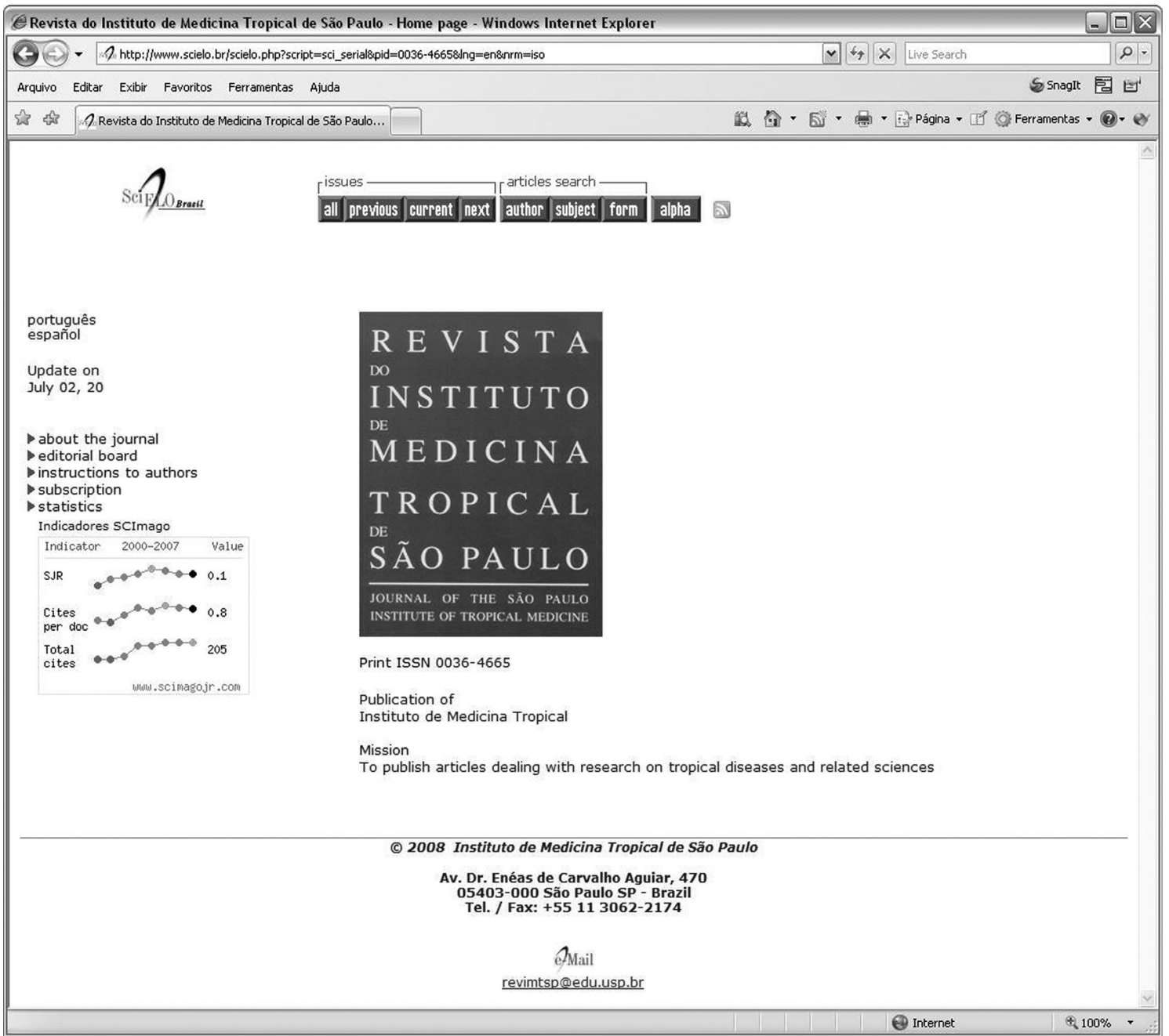

SciELO - The Scientific Electronic Library OnLine - SciELO is an electronic virtual covering a selected collection of Brazilian scientific journals.

The library is an integral part of a project being developed by FAPESP - Fundação de Amparo à Pesquisa do Estado de São Paulo, in partnership with BIREME - the Latin American and Caribbean Center on Health Sciences Information.

SciELO interface provides access to its serials collection via an alphabetic list of titles or a subject index or a search by word of serial titles, publisher names, city of publication and subject.

The interface also provides access to the full text of articles via author index or subject index or a search form on article elements such as author names, words from title, subject and words from full text.

FAPESP/BIREME Project on Scientific Electronic Publications Latin American and Caribbean Center on Health Sciences Information

Rua Botucatu 862 - 04023-901 São Paulo, SP - Brazil

Tel. (011) 5576-9863

scielo@bireme.br 